\title{
THE BENEFITS OF THE QUR'AN AS PROBLEM SOLVING FOR SANTRI'S LIFE: LIVING QUR'AN AT PESANTRENS IN TULUNGAGUNG
}

\author{
Ahmad Zainal Abidin \\ State Institute of Islamic Studies (IAIN) Tulungagung \\ ahmadzainal74@yahoo.com.sg
}

\begin{abstract}
Studies on the practices of Muslims in functioning the Qur'an in their daily lives have fewer number compared to studies on tafsir both textually and contextually. Whereas the former studies, referred to as Living Quran, are able to present tafsir of the Qur'an into the real world. Living Quran seeks to explain how Muslims perceive the Qur'an, read it, and treat its particular verses and surahs as pragmatic solution. This study aims to reveal, map, and record the uses of verses or surahs of the Qur'an as a solution for the life of santri at pesantren in Tulungagung, East Java, Indonesia. The method used in this study is in-depth interview. The collected data were analyzed descriptively using emic approach.The research shows how the practice runs naturally in the tradition of santri with the belief that the Qur'an has certain efficacies not merely as a remedy for psychic illness but also as a medicine for physical diseases and other needs.
\end{abstract}

Keywords: Efficacy, living Qur'an, practice, shifa', santri

\section{Introduction}

There recent study among the Qur'an reviewers is the living Qur'an study. Unlike the common studies high lighting the Qur'an from aspects of method, content, historical interpretation and the origin of the Qur'an, the living Qur'an study reviews Muslims' reception, response and practice of in relation to the Qur'an; how they treat and function the Qur'an for practical need sand purposes (Mansur, 2007, 5-9). It is also different from the interpretation methods established among traditional scholars of Qur'an who had searched and discovered God's intention in the texts, but attempts to reveal Muslims' receptions and responses to particular verses or surahs of the Qur'an which are recited, memorized, written, and applied (al-Salih, 1988, 17-18) in order to solve the problems faced in their lives. By this, the living Qur'an study employs a different method; it follows a general method of socio-anthropological research (Rohmana, 2015, 267-268).

There are few studies attempting to explain how Muslims perceive the Qur'an before the 2000s. It was after the 2000s that the living Qur'an study becomes a trend in recent years. In contrast to similar research aiming to describe Muslims' reception and practice in a certain case and activity, this study aims to reveal, map and record the practice and behavior of Muslims associated with the Qur'an in the tradition of some Islamic boarding schools (pesantren) students (santris) in Tulungagung, East Java, Indonesia.

Nelson (1985), Denny (1990), Abidin S. (1992), Federspiel (1994), Gade (2004), Wasik (2005), Syam (2007), Ahmad (2008), Rasmussen (2010), Lawrence (2011), 'Afifah (2011), Hidayah (2011), Kurniawan (2012), Mattson (2013), Mun'im (2013), Andriawan (2013), Rafiq (2014), and Anwar (2016) had done research on Muslim's attitude to ward the Qur'an. Yet, their focuses, objectives, locus and tempus are different from this study. However, their research paves the way as well as the previous studies of this research. 
The majority of Muslims is convinced that reciting certain verses or surahs of the Qur'an can solve psychic problems. The function of the Qur'an as syifa or medicine is believed to be a cure for psychic and mental illness (Q.S. Yunus (10): 57).Yet, some had believed more than that. It is widely understood that the Qur'an serves as not only a cure for psychic-spiritual but also physical diseases (Mustaqim, 2007, 69-70).

The problems are: 1 . How is the practice of using certain verses or surahs from the Qur'an for psychic-spiritual and physical diseases among santri(s) in Tulungagung? 2. How do santri(s) understand the practice of using and applying such verses or surahs for psychic-spiritual and physical diseases?

\section{Method}

This research is limited to a number of pesantrens chosen purposively due to easy access and affordability to do the research. The targeted pesantrens are PPHM Ngunut Tulungagung, PP Alfatah Mangunsari Tulungagung, Pondok Panggung Tulungagung, Pesantren Huffadz for female al-Yamani Sumbergempol Tulungagung, Pesantren Subulussalam Plosokandang Tulungagung and Pondok Pesantren Sirojuth Tholibin Plosokandang Tulungagung. The method used in this study is in-depth interview. Interviews are used to extract as much and deep data as possible about how santris recite and use the verses or surahs of the Qur'an and how they interpret the practice for a particular purpose (Yusuf, 2007, 57-60). The collected data were analyzed descriptively using emic approach i.e., looking at the socio-cultural phenomena on the basis of the community's point of view.

\section{Result and Discussion}

\section{Living Qur'an among Santri(s)}

There are many varieties of Living Qur'an practices found among santri(s) in Tulungagung. The variety is due to the diversity of understanding and problems faced by students and in viewing the status and function of the Qur'an. In line with Denny's theory that differentiates between two phenomena of Muslim response to the Qur'an, exegesis and recitation, the last theory is relevant to this research that Muslim of various cultural backgrounds perceives the Qur'an in their particular context for many purposes (Denny, 1985, 95-97). It is also in line with functional reception theory developed by Coward who sees that the scripture works as a "symbol" rather than a "sign"(Coward, 1988,182). In Qur'an reception as a sign, the reader uses Iser's concept of "textual structure," in which perspectives of the text are emphasized. In reception as a symbol, the reader is in a "structured act"(Iser, 1978, 35-37).

Among the practices found there were the uses of a talisman to chase jinn-satan away by using ayat kursi and muawwidhatain surahs (surah al-Falaq and al-Nas) as distress repellent surahs. The trick is to recite the surahs and verses any time and when someone needs protection from the satan. Some also recite ayat kursi not to cast out demons, but to fortify the house from theft. And again, it is done by reciting ayat kursi once or three times in such intention ( Interview with Hfd on April 11 2017).

Similar to the purpose of verse usage as a shield is another practice done by students to protect themselves from either physical or non-physical disturbance. According to MKL, for this reason he recites the last verses of surah al-Taubah which are "laqad ja'akum rasulun min anfusikum 'azizun 'alaih ma 'anittum haris|un 'alaikum bi al-mu 'minin ra' "ufun rahim” three times (Interview with Mkl on April 11 2017). One santri recites "wa iza batasytum batasytum jabbarin" verses to weaken the enemy who attacks either at home or not, regarding the possibility of its unforeseen occurrence. 
Another practice driving students to interact with the Qur'an is their expectation for sustenance or, in their words, to attract fortune. Hsn said that for this, surah al-Waqi'ah must be recited every day or as many as possible to help him gain material needs easily (Interview with Hsn on April 15 2017).

Another practice focuses on Santris' spiritual aspect that they recite particular verses of the Qur'an for a certain aim. A student of PP al-Fattah practiced a certain ritual to reveal the supernatural world or to be able to see supernatural beings like jinns. To see them, someone recites surah al-Jinn three times at night in a dark place with the intention to deliberately see jinns. It would be more effective by performing two raka'at of sunnat prayer before (Interview with Ahm on April 15 2017).

Another practice is using ayat as a house fence from the interference of spirits. This is to protect the householder from crimes that may come. According to Mkl, it can be done by writing ayat kursi on a piece of paper and then each is planted in four corners of the house in four directions: north, south, east and west.

The use of verses as a self-alarm to get up at the desired time is one of santris' habit especially to perform night prayers. For this aim, a student, Nl, is used to recite the last verses of surah al-Kahf which are "Qul innama ana basyarun mislukum yuhailayyannama ilahukum ilahun wahid Faman kana yarju liqa'a rabbihi fal ya'mal 'amalan shalihan wala yusyrik bi 'ibadatirabbih ahadan". This verse is recited once immediately before closing his eyes. For the same reason, another student recites another verse that is "Aqim al-salata li duluk al-syams ila gasaq al-layl wa qur'an al-fajr, inna qur'an al-fajr kana masyhudan ", three times before closing his eyes while thinking about the time he wished to awake (Interview with Nl on April 11 2017).

To treat common sickness, some students recite "wa iza maridtu fahuwa yasyfin" three times. This practice is done by using water drunk by the sick. Meanwhile, to heal a toothache, a student of Subulussalam, Nf, recites the last verse of surah Yasin which is "subhana al-lazi biyadihi malakut kull syay' wa ilayh turja'un," three times and blown toward his finger tips and massaged to the painful tooth (Interview with Nf on April 13 2017).

Human side of santri can be seen when they admit experiencing problems with feeling, feeling confused and falling in love. For this, they practice frequently reciting the Qur'an at the whole surah al-Dhuha. Meanwhile, to present mahabbah or love appeal toward the opposite sex, a student confesses reciting the $39^{\text {th }}$ verse of surah Thaha: "Aniqzifihi fi al-tabuti faqzifihifi al-yammi fal yulqihi al-yammubi al-sahil ya'khuzhu 'aduwwun li wa'aduwwunlah. Wa alqaitu 'alaika mahabbatan minni walitusna'a 'ala 'aini". This must be addressed to someone who is likely to be loved and not for someone belonged to others. This aims to keep other's feeling in order that things run peacefully and not to disturb another family (Interview with Mkl on April 12 2017). Another way to attract affection is by reciting surah al-Rahman once after each subuh and ashar prayers every day until the girl changes her mind (Interview with Mkl on April 12 2017).

The expectation for good children is one of research findings. To get wellbehaved sons and/or daughters, someone can recite "Astagfiru Allah al-'Azim 100 times, and followed by reciting shalawat to the Prophet (Allahumma salli 'ala sayyidina Muhammad wa 'ala ali sayyidina Muhammad) 100 times,then reciting Ya Latif 129 times, and praying "Rabbana hab lana min azwajina wazurriyyatina qurrata a'yun waj'alna li al-muttaqin imaman" once after each five time prayers. Another way to come to this purpose is found by another santri through reciting surah Yusuf. Furthermore, to get beautiful or handsome and wellbehaved children, someone could frequently recite surah Maryam (Interview with $\mathrm{Vv}$ on April 11 2017). 
The Qur'an is also believed to be able to save human from wild animals. This could be done by reciting the verse "Salamun 'ala Nuhin fi al-'alamin" as frequent as possible when facing animals that attack (Interview with Mbr on April 15 2017).

Supernatural knowledge seems also to exist among santri(s). A student told that reciting Qur'an could bend a bar of iron or steel especially for an emergency. It can be done by 12 days fasting and frequently reciting the $12^{\text {th }}$ verse of surah al-Hadid that is "Laqad arsalna rusulana bi al-bayyinat wa anzalna ma'ahum al-kitab wa al-mizan liyaqum al-nas bi al-qist. Wa anzalna al-hadid fihi ba'sun syadidun wama nafi' li al-nas wa liya 'lama Allah man yansuruhu warusulahu bi al-gaib. Inna Allah qawiyyun 'Azizun" (Interview with Vv on April 11 2017).

Another student's practice was found to find missing goods. This could be done by reciting the $70^{\text {th }}$ verse of surah al-Hajj three times without breathing. The verse is "Alam ta'lam anna Allah ya'lamuma fi al-sama'i wa al-ard. Inna zalika fi kitab Innazalika 'ala Allah yasir." It was similar to reciting "Ya Hafiz" 100 times, and the $16^{\text {th }}$ verse of surah Luqman that is "Ya bunayya innaha intakumisq al habbatin min khardalin fatakun fi sakhratin aw fi al-samawati aw fi al-ardy a'tibiha Allah. Inna Allah latifun khabir" (Interview with Hfd on April 15 2017). Also, to change thiefs' mind or to make them confused when stealing at a house is by reciting once at the house corner, and then reciting ayat kursi while walking around the house. In one round, ayat Kursi is recited 15 times in 3 rounds. Then, it is ended by reciting iqamah exactly at the corner adzan is recited.

The anticipatory vision on the road is also an inevitable part of santris. To avoid police operation on the road, a santri recites surah al-Kausar with basmalah. When reciting part of the verse: huwa al-abtar, at the word "ab" they have to stop for a moment and hold their breath while continuously reciting the word "tar tar tar"( Interview with Hfd on April 15 2017). Another practice for travel safety, particularly a long journey, is to recite surah Quraish 3 times before or when departing (Interview with Hsn on April 15 2017). For in or out of travel safety, the last four verses of surah al-Hasyr can also be recited (Interview with Znl on April 14 2017).

Santris who are taking exam either routine or incidental exams usually recite surah al-Insyirah three times and then reciting salawat to the Prophet PBUH which is: Salla Allah 'ala Muhammad three times. The two are recited when they are to answer the questions expecting to pass and gain easiness (Interview with Awr on April 11 2017). Giving birth process seems common to be regarded as a life and death process of a mother to be. In order to easily give birth, someone could frequently recite surah alQadr. Husbands are encouraged to be actively involved in wife's delivering birth (Interview with Nzl on April 12 2017).

The verse "Rabb isyrah li sadri wa yassir li amri wahlul 'uqdatan min lisani yafqahu qauli"is recited by some santris for certain intention mainly to open or deliver a speech or sermon to be easily understood by the audience and at the same time, it is hoped that the speaker would not get nervous and afraid of facing the audience.

From the data above, it is obvious that socio-pragmatic practice of Moslems reveals the unique understanding and interpretation of the Qur'an living among santri(s) in Tulungagung. This uniqueness asserts that the Qur'an is guidance for everyone, not only for scholars, but also for the majority of Muslims who attempt to respond and use the Qur'an according to their needs. The use of verses is are presentation of symbolic relationship between the weak and limited servant and the Supreme God. The language of the Qur'an which is believed to be the language of the sky is regarded as having a supernatural power to be used to present someone's resignation before the phenomena and difficulties they find. 
The findings of this research are in line with Darraz's argument $(1960,111)$, that the Qur'an is like apearl from which every angle gives a guidance to all through every direction; with Arkoun (1997, 50-60) who states that the Qur'an provides the possibility for people from different cultures to been thralled with its message and to feel the direct greetings of the Qur'an; with Shihab $(1992,133)$ who contends that the Qur'an was not only revealed for people in the Prophet's period only, the people of $20^{\text {th }}$ century, but also for everyone in every period with then ecessity of using the potential thoughts on them. This study confirmed the subjective hermeneutic opinions such as Hanafi $(1988,537)$ who considered the urgency of audience's interest as a judgment to interpret the Qur'an.

\section{Conclusion}

It may be concluded from the discussion above that, First, santri(s) of Pesantrens in Tulungagung perceive the Qur'an not only as a cure for psychical illness but also as a solution for any problems faced just by reciting some verses or surahs in a particular way. Secondly, they treat the Qur'an in accordance with their pragmatic needs: to chase the satan away, expedite the fortune, fortify the house from disturbance, evict the spirit disturbance, gain good-looking and well-behaved children, keep away from both physicalnon physical disturbances, weaken the enemy, unmask the supernatural world, awaken at the desired hour, treat the sickin cluding toothaches, present the appeal of love to the opposite sex, bendiron or steel, search for lost items, find thieves, expedite travel, deliver speech to be acceptable, and remove the sins.

\section{References}

Abidin S., Zainal, 1992, Seluk Beluk al-Qur'an. Jakarta: Rinaka Cipta.

'Afifah, Zulfa, 2011, Simaan al-Qur'an dalam Tradisi Rasulan. Thesis. The Faculty of Ushuluddin dan Pemikiran Islam Yogyakarta.

Ahmad, Farkhani, 2008, Penggunaan Ayat-ayat al-Qur'an dalam Ritual Pager Desa di Desa Jetis Juwiring Klaten. Thesis. The Faculty of Ushuluddin dan Pemikiran Islam Yogyakarta.

AlAyyubi, Sholahuddin, 2016, Teks Agama dalam Transmisi Teks Magi di Masyarakat Banten: Studi Living Hadis. Holistic al-Hadis Jurnal Studi Hadis, KeindonesiaandanIntegrasiKeilmuan02 (01):131-172.

Andriawan, Didik, 2013, Penggunaan ayat al-Qur'an sebagai Pengobatan; Studi Living Qur'an pada Praktek Pengobatan Dr. KH Komari Saifullah Pesantren Sunan Kalijaga Desa Pakuncen Kecamatan Patianrowo, Kabupaten Nganjuk. Thesis. The Faculty of Ushuluddin dan Pemikiran Islam Yogyakarta.

Arkoun, Mohammed, 1997, Berbagai Pembacaan al-Qur'an. Translated by Machasin. Jakarta: INIS.

Coward, Harol.1988. Sacred Word and Sacred Text. New York: Orbis Book.

Darraz, 'Abd Allah, 1960. al-Naba' al- 'Azim. Mesir: Dar al-'Arubah.

Denny, Frederic M, 1990, Adab Membaca al-Qur'an: Teks Konteks. Ulumul Qur'an Jurnal Ilmu Dan Kebudayaan (02):54-63.

Denny, Frederick M. 1985. Islam: Qur'an and Hadith. in The Holy Book in Comparative Perspective, edited by F.M. Deny and Rodney L. Taylor. Columbia: University of South Carolina Press.

Federspiel, Howard M, 1994, Popular Indonesia Literature of the Qur'an. New York: Cornel Modern Indonesia Project.

Gade, Anna M. 2004. Perfection Makes Practice: Learning, Emotion, and the Recited Qur'an in Indonesia. Honolulu: University of Hawai Press.

Gazali, Hatim \& Abd. Malik,"Pesantren and the Freedom of Thinking: Study of Ma“had 
Aly Pesantren Sukorejo Situbondo, East Java, Indonesia", in Al-Jami 'ah, Vol. 47, No. 2, 2009 M./1430 H.: 293-315.

Gusmian, Islah. 2013. Khazanah Tafsir Indonesia Dari Hermeneutika Hingga Ideologi Yogyakarta: LKiS.

Hanafi,Hassan. 1988. Dirasah Falsafiyyah. Kairo: Maktabah Anglo-Misriyyah.

Hidayah, Aida. 2011. Penggunaan Ayat-ayat al-Qur'an sebagai Metode Pengobatan bagi Penyakit Jasmani Studi Living Qur'an. Thesis. The Faculty of Ushuluddin dan Pemikiran Islam Yogyakarta.

Iser, Wolfgang. 1978. The Act of Reading: Theory of Aesthetic Response. Baltimore: John Hopkins University Press.

Kurniawan, Edi. 2012. Bacaan al-Qur'an pada Ayyamul Byd, Studi Living Qur'an di Kampung Sudimoro Giriharjo Panggung Gunung Kidul. Thesis. The Faculty of Ushuluddin dan Pemikiran Islam Yogyakarta.

Lawrence, Bruce. 2011. Biografi al-Qur'an, translated by Ahmad Asnawi Yogyakarta: Diglossia.

M. Mansur. 2007. Living Qur'an dalam Lintasan Sejarah Studi Qur'an, in Sahiron Syamsuddin (editor), Metodologi Penelitian Living Qur'an dan Hadis. Yogyakarta: TH Press and Teras.

Mattson, Inggrid. 2013. The Story of the Qur'an: Its History and Place in Muslim Life. West Sussex: Wiley-Blackwell.

Mujahidin, Anwar. 2016. Analisis Simbolik Penggunaan Ayat-ayat al-Qur'an sebagai Jimat dalam Kehidupan Masyarakat Ponorogo. Kalam 10 (1):43-64.

Mun'im, A Rofiq Zainul. 2013. Al-Qur'an dalam Kehidupan Masyarakat Studi tentang Simbolisasi dan Pemaknaan Ayat-ayat al-Qur'an bagi Masyarakat Probolinggo Jawa Timur. Dissertation. IAIN Sunan Ampel Surabaya.

Mustaqim, Abdul. 2007. Metode Penelitian Living Qur'an Metode Penelitian Kualitatif, in Sahiron Syamsuddin (editor), Metodologi Penelitian Living Qur'an dan Hadis. Yogyakarta: TH Press and Teras.

Nelson, Kristina. 1985.The Art of Reciting the Qur'an. Cairo: American University of Cairo Press.

Rafiq, Ahmad. 2014. The Reception of the Qur'an in Indonesia: A Case Study of the Place of the Qur'an in a Non-Arabic Speaking Community. Dissertation, Temple University.

Rasmussen, Anne K. 2010. Women, the Recited Qur'an, and Islamic Music in Indonesia. Berkeley: University of California Press.

Rohmana, Jajang A. 2015. Pendekatan Antropologi dalam Studi Living Hadis di Indonesia: Sebuah Kajian Awal. Holistic al-Hadis Jurnal Studi Hadis, Keindonesiaandan Integrasi Keilmuan 01 (02): 247-288.

Salih, Subhi al-. 1988. Mabahis fi 'Ulum al-Qur'an. Beirut: Dar al-'Ilm li al-Malayin.

Shihab, M. Quraish. 1992. Membumikan al-Qur'an Fungsi dan Peran Wahyu dalam KehidupanMasyarakat. Bandung:Mizan.

Syam, Nur. 2007. Islam Pesisir. Yogyakarta: Islam Pesisir.

Wasik, Moh. Ali. 2005. Fenomena Pembacaan al-Qur'an dalam Masyarakat Padukuhan Sumbung Pleret Bantul. Thesis. The Faculty of Ushuluddin dan Pemikiran Islam Yogyakarta.

Yusuf, Muhammad. 2007. "Pendekatan Sosiologi dalam Penelitian Living Qur'an". Sahiron Syamsuddin, Metodologi Penelitian Living Qur'an dan Hadis. Yogyakarta: TH Press and Teras.

Interview:

An Interview with Awr on April 112017. 
An Interview with Mkl on April 112017. An Interview with Vv on April 112017. An Interview with N1 on April 112017 An Interview with Nzl on April 122017. An Interview with Mkl on April 122017. An Interview with Mkl on April 122017. An Interview with Nf on April 132017. An Interview with Znl on April 142017. An Interview with Mbr on April 152017. An Interview with Hfd on April 152017. An Interview with Hsn on April 152017. An Interview with Ahm on April 152017. 